Article

\title{
Treatability of a Highly-Impaired, Saline Surface Water for Potential Urban Water Use
}

\section{Frederick Pontius}

Department of Civil Engineering and Construction Management, Gordon and Jill Bourns College of Engineering, California Baptist University, Riverside, CA 92504, USA; fpontius@calbaptist.edu; Tel.: +1-951-343-4846

Received: 14 January 2018; Accepted: 14 March 2018; Published: 15 March 2018

\begin{abstract}
As freshwater sources of drinking water become limited, cities and urban areas must consider higher-salinity waters as potential sources of drinking water. The Salton Sea in the Imperial Valley of California has a very high salinity (43 ppt), total dissolved solids $(70,000 \mathrm{mg} / \mathrm{L})$, and color $(1440 \mathrm{CU})$. Future wetlands and habitat restoration will have significant ecological benefits, but salinity levels will remain elevated. High salinity eutrophic waters, such as the Salton Sea, are difficult to treat, yet more desirable sources of drinking water are limited. The treatability of Salton Sea water for potential urban water use was evaluated here. Coagulation-sedimentation using aluminum chlorohydrate, ferric chloride, and alum proved to be relatively ineffective for lowering turbidity, with no clear optimum dose for any of the coagulants tested. Alum was most effective for color removal (28 percent) at a dose of $40 \mathrm{mg} / \mathrm{L}$. Turbidity was removed effectively with $0.45 \mu \mathrm{m}$ and $0.1 \mu \mathrm{m}$ microfiltration. Bench tests of Salton Sea water using sea water reverse osmosis (SWRO) achieved initial contaminant rejections of 99 percent salinity, 97.7 percent conductivity, 98.6 percent total dissolved solids, 98.7 percent chloride, 65 percent sulfate, and 99.3 percent turbidity.
\end{abstract}

Keywords: coagulation; desalination; Salton Sea; sea water reverse osmosis; treatability

\section{Introduction}

Many inland bodies of water suffer from rising salinity which can harm biota and impair or prevent beneficial water use [1]. Salinization occurs when salts and minerals in soil are mobilized from clearing natural vegetation [2], when fresh water is diverted for irrigation [3], there are ongoing or reoccurring drought conditions [4], or as a result of municipal wastewater discharges [5]. As freshwater sources of drinking water become limited, cities and urban areas must consider higher-salinity waters as potential sources of drinking water.

The Salton Sea is a large, shallow saline lake in an arid desert area of Southern California. It was formed by an accidental diversion of the Colorado River into the Salton Sink between 1905 and 1907. The lake is the largest and lowest inland water body in California with a total surface area of $980 \mathrm{~km}^{2}$, a maximum depth of approximately $15 \mathrm{~m}$, and approximately $70 \mathrm{~m}$ below mean sea level. It is a closed-basin lake with no outlet, sustained by irrigation return flows and municipal wastewater discharges. Initially a freshwater lake, a high nutrient loading from agricultural runoff, continuous municipal wastewater treatment effluent discharges, and no natural outflow has resulted in a steady decline in water quality over many decades [6]. Diversion of agricultural water to municipal use beginning 1 January 2018 further threatens water quality, but is also expected to result in further shrinking the size of the Salton Sea [7].

The Salton Sea has been the subject of significant research, and its water quality deterioration is well characterized [8-11]. Despite being a hypereutrophic, hypersaline water body, the Salton Sea provides a significant ecological function, and is a vital habitat for migrating birds. Development and implementation of plans to remediate the Salton Sea ecosystem has been an ongoing challenge 
for the California Department. of Water Resources [7] and the approximately 650,000 people living with the air basin impacted by dust from the sea [12]. Indeed, the economic cost of doing nothing to remediate the Salton Sea far outweigh the cost of remediation proposals [12]. Various alternatives to remediate the ecosystem have been put forth by stakeholders and evaluated by the U.S. Bureau of Reclamation [13]. Alternatives generally involve wetlands and habitat restoration using shallow water impoundment dikes. Construction of a desalination reverse osmosis (RO) plant has also been proposed to produce freshwater for potential urban or groundwater recharge uses [14]. Importation of water from Mexico has also been proposed as a way to maintain sea water at a sustainable level [15]. In November 2017, the California Water Resources Control Board accepted a 10-year plan to construct 29,800 acres of ponds, wetlands, and dust suppression projects on the exposed lake bed [16]. Future habitat restoration and dust suppression will have significant benefits for ecological restoration, but salinity concentrations will still be too high for the Salton Sea to serve as a potential urban water supply without desalination.

In practice, industrial water desalination is most often accomplished using one of four processes: multi-stage flash distillation, multiple effect distillation, vapor-compression evaporation and RO [17]. These technologies are primarily limited by high energy costs, a large concentrate (brine) waste discharge, and the need to pump water from the sea. RO typically consumes less than 10 to 50 percent of the total equivalent energy required by other desalination technologies [18]. Further, RO is commonly used for drinking water treatment in the United States when desalination is necessary, with application of other desalination processes generally limited to industrial water treatment. Even so, multi-effect distillation with a vertical tube evaporator is being tested by the U.S. Bureau of Reclamation for geothermal distillation of Salton Sea water [19]. On the southeast bank of the Salton Sea is a seismically active geothermal field under consideration for future geothermal energy development [20-22].

This present study explores the treatability of Salton Sea water for potential urban water use when other options are limited or non-existent. The quality and treatability of Salton Sea water is compared to that of Pacific Ocean water using jar tests and $\mathrm{RO}$ desalination. RO was evaluated here because of its familiarity within the drinking water industry and low energy requirements compared to other desalination processes. Because of its high salinity, Salton Sea water is expected to cause severe chemical fouling of $\mathrm{RO}$ membranes on a long-term basis, unless pretreatment is provided. The initial tests of $\mathrm{RO}$ technology conducted here are intended primarily to assess contaminant rejection. Should contaminant rejection using $\mathrm{RO}$ with minimal pretreatment be effective, future studies could be considered to optimize pretreatment and evaluate long-term $\mathrm{RO}$ performance.

\section{Materials and Methods}

The effectiveness of RO treatment of Salton Sea water and Pacific Ocean water was evaluated at the bench scale. Pretreatment of Salton Sea water using cartridge filtration and coagulation was also assessed.

In August 2017, multiple 19 L containers of water were taken from the Salton Sea north shore and the Pacific Ocean at Cabrillo Park, California, and transported to the environmental engineering laboratory at California Baptist University (CBU). Raw Salton Sea water (SSW) and Pacific Ocean water (POW) samples were tested for the constituents listed in Table 1, which summarizes the sampling plan followed in this study. A process flow diagram and sampling locations are provided in Figure 1.

\subsection{Cartridge Filtration}

After collection, SSW and POW samples were filtered through a $30 \mu \mathrm{m}$ spiral-wound cartridge filter prior to further testing. 


\subsection{Coagulation}

Jar tests were performed on Salton Sea water to assess the effectiveness of coagulation for color removal. Aluminum chlorohydrate $(\mathrm{ACH})$, ferric chloride (ferric), and aluminum sulfate (alum) were evaluated.

Table 1. Sampling and Analysis Plan ${ }^{1}$.

\begin{tabular}{ccccccccc}
\hline \multirow{2}{*}{ Constituent } & \multicolumn{3}{c}{ Salton Sea Water } & \multicolumn{3}{c}{ Pacific Ocean Water } \\
\cline { 2 - 8 } & Raw & Filt & Perm & Reject & Raw & Filt & Perm & Reject \\
\hline Alkalinity & $\mathrm{X}$ & $\mathrm{X}$ & $\mathrm{X}$ & $\mathrm{X}$ & $\mathrm{X}$ & $\mathrm{X}$ & $\mathrm{X}$ & $\mathrm{X}$ \\
Aeromonas & $\mathrm{X}$ & - & - & - & $\mathrm{X}$ & - & - & - \\
Ca $^{2+}$ Hardness & $\mathrm{X}$ & $\mathrm{X}$ & $\mathrm{X}$ & $\mathrm{X}$ & $\mathrm{X}$ & $\mathrm{X}$ & $\mathrm{X}$ & $\mathrm{X}$ \\
Chloride & $\mathrm{X}$ & - & $\mathrm{X}$ & $\mathrm{X}$ & $\mathrm{X}$ & - & $\mathrm{X}$ & $\mathrm{X}$ \\
Color & $\mathrm{X}$ & - & $\mathrm{X}$ & $\mathrm{X}$ & $\mathrm{X}$ & - & $\mathrm{X}$ & $\mathrm{X}$ \\
Conductivity & $\mathrm{X}$ & - & $\mathrm{X}$ & $\mathrm{X}$ & $\mathrm{X}$ & - & $\mathrm{X}$ & $\mathrm{X}$ \\
E. coli & $\mathrm{X}$ & $\mathrm{X}$ & $\mathrm{X}$ & $\mathrm{X}$ & $\mathrm{X}$ & $\mathrm{X}$ & $\mathrm{X}$ & $\mathrm{X}$ \\
HPC & $\mathrm{X}$ & $\mathrm{X}$ & $\mathrm{X}$ & $\mathrm{X}$ & $\mathrm{X}$ & $\mathrm{X}$ & $\mathrm{X}$ & $\mathrm{X}$ \\
pH & $\mathrm{X}$ & - & $\mathrm{X}$ & $\mathrm{X}$ & $\mathrm{X}$ & - & $\mathrm{X}$ & $\mathrm{X}$ \\
Salinity & $\mathrm{X}$ & - & $\mathrm{X}$ & $\mathrm{X}$ & $\mathrm{X}$ & - & $\mathrm{X}$ & $\mathrm{X}$ \\
Sulfate & $\mathrm{X}$ & - & $\mathrm{X}$ & $\mathrm{X}$ & $\mathrm{X}$ & - & $\mathrm{X}$ & $\mathrm{X}$ \\
Suspended Solids & $\mathrm{X}$ & - & $\mathrm{X}$ & $\mathrm{X}$ & $\mathrm{X}$ & - & $\mathrm{X}$ & $\mathrm{X}$ \\
Total Coliform & $\mathrm{X}$ & - & - & - & $\mathrm{X}$ & - & - & - \\
Total Hardness & $\mathrm{X}$ & - & $\mathrm{X}$ & $\mathrm{X}$ & $\mathrm{X}$ & - & $\mathrm{X}$ & $\mathrm{X}$ \\
Total Solids & $\mathrm{X}$ & - & $\mathrm{X}$ & $\mathrm{X}$ & $\mathrm{X}$ & - & $\mathrm{X}$ & $\mathrm{X}$ \\
Turbidity & $\mathrm{X}$ & $\mathrm{X}$ & $\mathrm{X}$ & $\mathrm{X}$ & $\mathrm{X}$ & $\mathrm{X}$ & $\mathrm{X}$ & $\mathrm{X}$ \\
UV254 & $\mathrm{X}$ & - & $\mathrm{X}$ & $\mathrm{X}$ & $\mathrm{X}$ & - & $\mathrm{X}$ & $\mathrm{X}$ \\
\hline
\end{tabular}

Note: ${ }^{1} \mathrm{HPC}=$ heterotrophic plate count; Filt $=30 \mu \mathrm{m}$ filtered; Perm $=$ RO permeate; Reject $=$ RO concentrate; $\mathrm{X}=$ analysis was performed; - = analysis was not performed

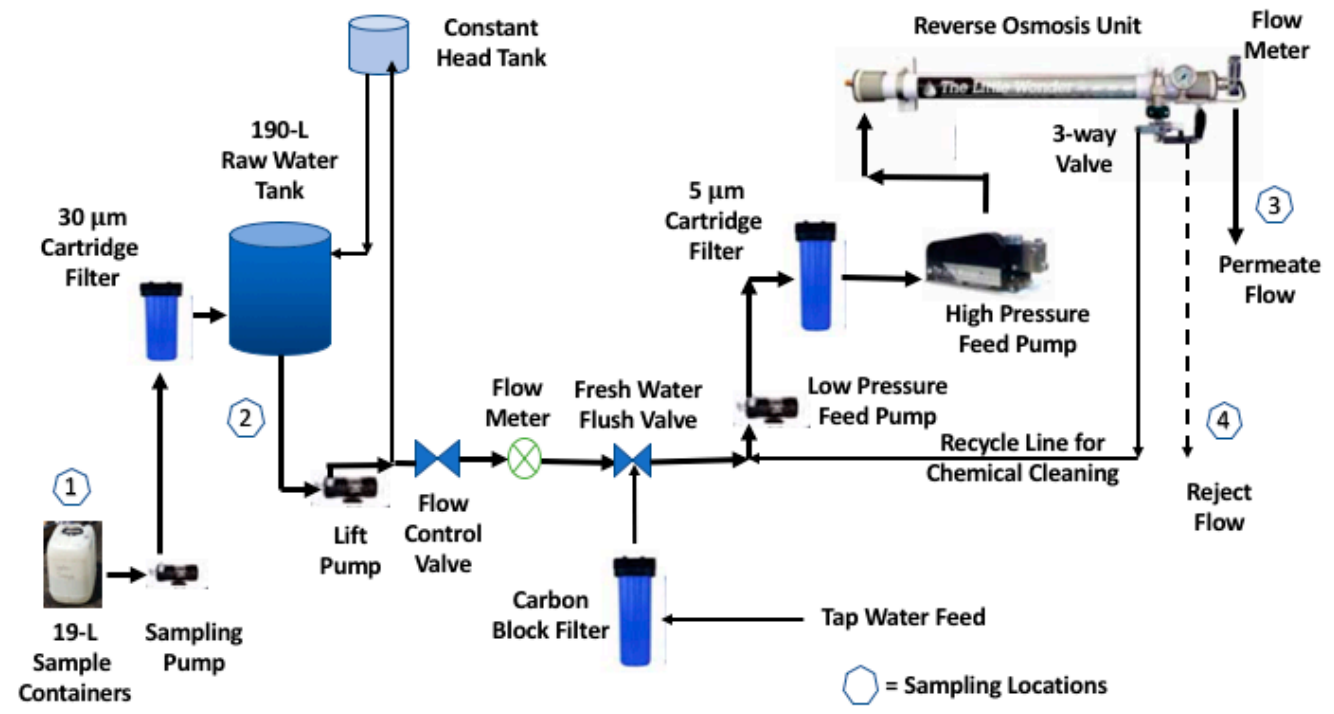

Figure 1. Process flow diagram and sampling locations.

\subsubsection{Jar Testing}

A series of jar tests were conducted following ASTM D 2035-08, Standard Practice for Coagulation-Flocculation Jar Test of Water [23]. Stock solutions were prepared for each coagulant at a concentration of 10,000 mg/L. A jar test was conducted for each coagulant at doses of $0,10,20,30,40$, and $50 \mathrm{mg} / \mathrm{L}$. Coagulants were added with rapid mixing for $2 \mathrm{~min}$, slow mixing for $30 \mathrm{~min}$ (tapered at 
$10 \mathrm{~min}$ intervals), and settling for $45 \mathrm{~min}$. Aliquots were taken from each jar for analysis of turbidity, $\mathrm{pH}$, alkalinity, and color.

The effectiveness of filtration pretreatment was assessed by filtering settled jar test samples through filters with consecutively smaller nominal pore sizes. Sand filtration was simulated by passing settled water through Whatman $40(8 \mu \mathrm{m})$ paper filters (Fisher Scientific, Waltham, MA, USA). Microfiltration was simulated by passing settled water through a $0.45 \mu \mathrm{m}$ membrane filter followed by a $0.1 \mu \mathrm{m}$ membrane filter using vacuum filtration.

\subsubsection{Bench RO Treatment}

The effectiveness of RO treatment was assessed at the bench scale by passing approximately $75 \mathrm{~L}$ of filtered Salton Sea water through a sea water reverse osmosis (SWRO) unit described in Table 2. Samples of feed water, permeate and concentrate were collected and analyzed according to the sampling plan presented in Table 1. For comparison, an identical SWRO treatment test was performed on Pacific Ocean water.

Table 2. Bench Scale Sea Water Reverse Osmosis (SWRO) System Specifications [24].

\begin{tabular}{|c|c|}
\hline Item & Design Criteria \\
\hline Manufacturer & Parker Hannifin Corp./Village Marine \\
\hline Model No. & LWM-200 \\
\hline No. Modules & 1 \\
\hline Module Diameter & 4-inch \\
\hline Module Length & 40 -inch \\
\hline No. Elements & $\begin{array}{c}1 \text { (Aqua Pro }{ }^{\circledR} \text { Sea Water RO Membrane (Parker Hannifin Corp., } \\
\text { Gardena, California, CA, USA) }\end{array}$ \\
\hline Membrane Type & Thin-Film Composite \\
\hline Membrane Surface Area & $1 \mathrm{~m}^{2}$ (estimated) \\
\hline Pre-filter & $\begin{array}{c}\text { Pentek }^{\circledR} 5 \mu \mathrm{m} \text { polypropylene (Pentair) (Parker Hannifin Corp., } \\
\text { Gardena, California, CA, USA) }\end{array}$ \\
\hline High-Pressure Pump & 708 Titan Series (Aqua Pro Pumps, Gardena, California, CA, USA) \\
\hline Max. Operating Pressure & $1000 \mathrm{psi}$ \\
\hline Max. Operating Temp. & $45^{\circ} \mathrm{C}$ \\
\hline Design Flux & $30 \mathrm{Lmh}$ (estimated) \\
\hline Design Product Flow & $0.8 \mathrm{~m}^{3} /$ day $(210 \mathrm{gpd})$ \\
\hline Max. Feed Turbidity & NTU $^{1}$ \\
\hline Free Chlorine Tolerance & $0 \mathrm{ppm}(5 \mu \mathrm{m}$ carbon block filter provided $)$ \\
\hline Max. Feed SDI ${ }^{1}$ & SDI 5 \\
\hline Typical Salt Rejection & 99.0 percent \\
\hline $\mathrm{pH}$ range & 4 to 11 ( 2.5 to 11 during short-term cleaning) \\
\hline
\end{tabular}

Note: ${ }^{1}$ Silt Density Index.

Feed water was pumped through the SWRO system at $20 \mathrm{~L} / \mathrm{h}$ for $60 \mathrm{~min}$ at 58 to $66 \mathrm{bar}$ transmembrane pressure (TMP). Samples were taken for analysis of the SWRO feed water, permeate, and reject stream. Initial contaminant rejection was assessed by taking composite samples over the $60 \mathrm{~min}$ operating period. TMP, permeate flow, and reject water flow were monitored during the test. The volume of water treated $(20 \mathrm{~L})$ and duration of testing $(60 \mathrm{~min})$ was limited, due to having to transport raw water to the laboratory for testing. Given the short-term of testing, normalization of test results was not necessary.

\section{Analytical Methods}

All analyses were performed at the CBU environmental engineering laboratory. The analytes and analytical methods used are presented in Table 3. Standard Methods [25], U.S. Environmental Protection Agency (EPA) methods [26], or their equivalent as developed by Hach [27] and Micrology Laboratories [28], were used. Quality assurance (AQ) and quality control $(\mathrm{QC})$ measures were followed along standard laboratory practices for instrument calibration according to the manufacturer's instructions. Filtration through a $0.45 \mu \mathrm{m}$ membrane filter was performed prior to ultraviolet 
absorbance (UVA) (Hach DR5000 UV VIS, Loveland, Colorado, CO, USA) and 254 nm (UV254) (Hach DR5000 UV VIS, Loveland, Colorado, CO, USA). All experiments and analyses were performed at laboratory temperature $\left(22^{\circ} \mathrm{C}\right)$.

Table 3. Analytical Methods.

\begin{tabular}{ccc}
\hline Analyte & Technique & Analytical Method \\
\hline Alkalinity & Titrimetric, pH 4.5 & EPA Method 310.1 \\
Aeromonas & Easygel ECA Check ${ }^{*}$ & Standard Methods $9223^{*}$ \\
Ca $^{2+}$ Hardness & Titrimetric, EDTA & Hach Method 8204 \\
Chloride & Mercuric Nitrate Titration & Hach Method 8206 \\
Color & Platinum-Cobalt & Standard Methods 2120 \\
Conductivity & Conductivity Cell & Standard Methods 2510 \\
HPC & Easygel Total Count T-salt ${ }^{1}$ & Standard Methods $9215 \mathrm{~B}^{*}$ \\
pH & Electrometric & EPA Method 150.1 \\
Salinity & Mercuric Nitrate Titration & Hach Method 10073 \\
Sulfate & Turbidimetric & Hach Method 10227 \\
Suspended Solids & Gravimetric & EPA Method 160.1 \\
Total Coliform & Easygel ECA Check ${ }^{1}$ & Standard Methods $9223 *$ \\
Total Hardness & Titrimetric, EDTA & Hach Method 8213 \\
Total Solids & Gravimetric & EPA Method 160.1 \\
Turbidity & Nephelometer & EPA Method 180.1 \\
UV254 & UVA at 254 nm & EPA Method 415.3 \\
\hline
\end{tabular}

Note: ${ }^{1}$ Micrology Laboratory, Goshen, Indiana, IN, USA; * Modified pour plate method developed by the manufacturer (Micrology Laboratory, Goshen, Indiana, IN, USA).

\section{Results and Discussion}

Results of water quality testing, cartridge filtration, jar testing, and SWRO bench testing are presented below. Analytical results for all water quality tests are presented in Tables 4 and 5 for SSW and POW, respectively.

Table 4. Salton Sea Water Analytical Results ${ }^{1}$.

\begin{tabular}{cccccc}
\hline \multirow{2}{*}{ Constituent } & Units & \multicolumn{4}{c}{ Salton Sea Water } \\
\cline { 3 - 5 } & & Raw & Feed & Permeate & Reject \\
\hline Alkalinity & $\mathrm{mg} / \mathrm{L} \mathrm{as} \mathrm{CaCO}_{3}$ & 276 & 268 & 12 & 288 \\
Aeromonas & $\mathrm{CFU} / \mathrm{mL}^{2}$ & 33 & - & - & - \\
$\mathrm{Ca}^{2+}$ Hardness & $\mathrm{mg} / \mathrm{L} \mathrm{as} \mathrm{CaCO}_{3}$ & 2200 & 2050 & 14 & 2200 \\
Chloride & $\mathrm{mg} \mathrm{Cl} / / \mathrm{L}$ & 38,000 & 25,400 & 500 & 27,700 \\
Color & $\mathrm{CU}$ & 1440 & 1300 & 58 & 127 \\
Conductivity & $\mathrm{mS} / \mathrm{m}$ & 71.9 & 71.3 & 1.65 & 77.0 \\
HPC & $\mathrm{CFU} / \mathrm{mL}$ & 66 & 32 & 14 & 122 \\
pH & units & 8.1 & - & 7.9 & 8.06 \\
Salinity & $\mathrm{ppt}$ & 43 & 39 & 0.4 & 46.7 \\
Sulfate & $\mathrm{mg} \mathrm{SO}{ }^{2-} / \mathrm{L}$ & 20,800 & 17,700 & $\mathrm{ND}$ & 19,500 \\
Suspended Solids & $\mathrm{mg} / \mathrm{L}$ & 44 & - & $\mathrm{ND}$ & 162 \\
Total Coliform & $\mathrm{CFU} / \mathrm{mL}^{-}$ & 37 & - & - & - \\
Total Hardness & $\mathrm{mg} / \mathrm{L} \mathrm{as} \mathrm{CaCO}_{3}$ & 17,500 & 9300 & 38 & 10,900 \\
Total Solids & $\mathrm{mg} / \mathrm{L}$ & 70,200 & - & 913 & 77,136 \\
Turbidity & $\mathrm{NTU}$ & 25.1 & 11.6 & 0.16 & 10.6 \\
UV254 & $\mathrm{cm}^{-1}$ & 0.696 & 0.69 & 0.013 & 0.815 \\
\hline
\end{tabular}

Note: ${ }^{1} \mathrm{HPC}=$ heterotrophic plate count; Filtered $=30 \mu \mathrm{m}$ filtered; Permeate $=$ RO permeate; Reject $=$ RO concentrate; $\mathrm{ND}=$ none detected; $\mathrm{CFU}=$ colony forming units. 
Table 5. Pacific Ocean Water Analytical Results ${ }^{1}$.

\begin{tabular}{cccccc}
\hline \multirow{2}{*}{ Constituent } & \multirow{2}{*}{ Units } & \multicolumn{4}{c}{ Pacific Ocean Water } \\
\cline { 3 - 5 } & & Raw & Feed & Permeate & Reject \\
\hline Alkalinity & $\mathrm{mg} / \mathrm{L} \mathrm{as} \mathrm{CaCO}_{3}$ & 126 & 124 & 10 & 168 \\
Aeromonas & $\mathrm{CFU} / \mathrm{mL}^{2}$ & $\mathrm{None}$ & - & - & - \\
$\mathrm{Ca}^{2+}$ Hardness & $\mathrm{mg} / \mathrm{L} \mathrm{as} \mathrm{CaCO}_{3}$ & 900 & 875 & 4 & 1250 \\
Chloride & $\mathrm{mg} \mathrm{Cl}-/ \mathrm{L}$ & 18,800 & 18,300 & 380 & 24,000 \\
Color & $\mathrm{CU}$ & $\mathrm{ND}$ & $\mathrm{ND}$ & $\mathrm{ND}$ & 1 \\
Conductivity & $\mathrm{mS}$ & 48 & 47 & 0.82 & 60 \\
HPC & $\mathrm{CFU} / \mathrm{mL}$ & 2047 & 243 & 1 & 3470 \\
pH & $\mathrm{units}$ & 8.0 & - & 7.5 & 8.0 \\
Salinity & $\mathrm{ppt}$ & 30.3 & 30.6 & 0.2 & 39.2 \\
Sulfate & $\mathrm{mg} \mathrm{SO}{ }^{2-} / \mathrm{L}$ & 262 & 263 & $\mathrm{ND}$ & 334 \\
Suspended Solids & $\mathrm{mg} / \mathrm{L}$ & 9 & - & 1 & 8 \\
Total Coliform & $\mathrm{CFU} / \mathrm{mL}^{2}$ & $\mathrm{None}$ & - & - & - \\
Total Hardness & $\mathrm{mg} / \mathrm{L} \mathrm{as} \mathrm{CaCO}_{3}$ & 4700 & 4900 & 24 & 8800 \\
Total Solids & $\mathrm{mg} / \mathrm{L}$ & 39,443 & - & 410 & 47,121 \\
Turbidity & $\mathrm{NTU}$ & 0.491 & 0.5 & 0.229 & 1.85 \\
UV254 & $\mathrm{cm}{ }^{-1}$ & 0.017 & 0.016 & 0.015 & 0.13 \\
\hline
\end{tabular}

Note: ${ }^{1} \mathrm{HPC}=$ heterotrophic plate count; Feed $=30 \mu \mathrm{m}$ filtered; Permeate $=$ RO permeate; Reject $=$ RO concentrate; $\mathrm{ND}=$ none detected.

\subsection{Cartridge Filtration}

Salton Sea water and Pacific Ocean water were filtered through a $30 \mu \mathrm{m}$ cartridge filter prior to performing SWRO bench tests. Turbidity removal of 54 percent was achieved for SSW. No significant removal of turbidity was achieved using a cartridge filter for POW because of the low raw water turbidity.

\subsection{Water Quality Test Results}

Consistent with prior studies, the Salton Sea water quality was found to be highly saline (43 ppt). The SSW chloride and total dissolved solids (= total solids - suspended solids) concentrations were $38,000 \mathrm{mg} \mathrm{Cl}^{-} / \mathrm{L}$ and 70,000 $\mathrm{mg} / \mathrm{L}$, respectively. In contrast, POW chloride and total dissolved solids concentrations were $18,800 \mathrm{mg} \mathrm{Cl}^{-} / \mathrm{L}$ and $39,434 \mathrm{mg} / \mathrm{L}$, respectively.

\subsection{Jar Test Results}

The Salton Sea is highly colored. Results of jar testing are presented in Figures 2-7. Coagulation-sedimentation proved to be relatively ineffective for lowering turbidity with no clear optimum dose for any of the coagulants tested (Figures 2-4). 


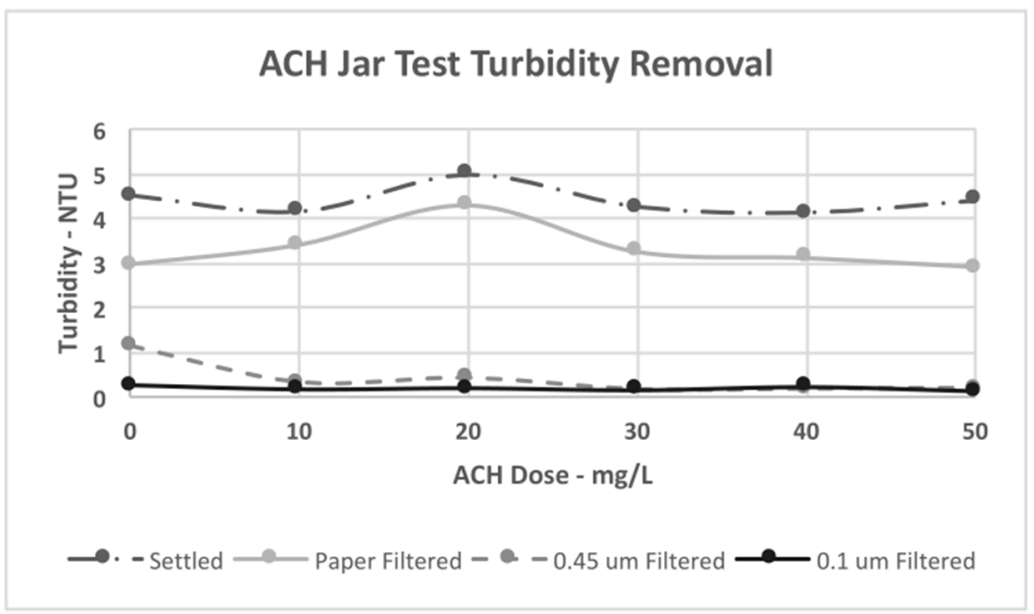

Figure 2. Turbidity after settling versus $\mathrm{ACH}$ dose and filtering through $8 \mu \mathrm{m}$ filter paper, a $0.45 \mu \mathrm{m}$ membrane filter, and a $0.1 \mu \mathrm{m}$ membrane filter.

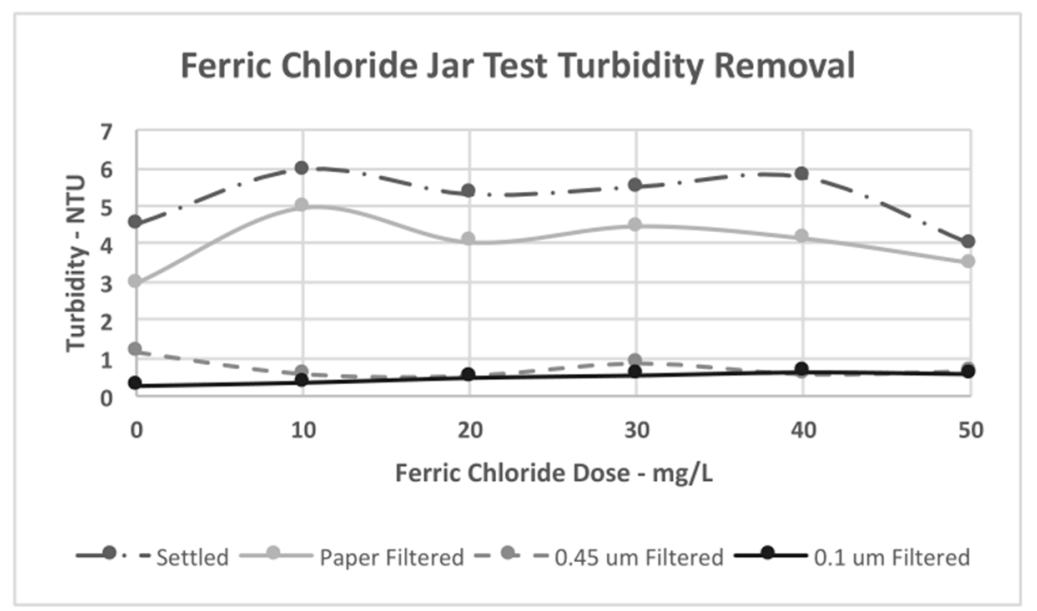

Figure 3. Turbidity after settling versus ferric dose and filtering through $8 \mu \mathrm{m}$ filter paper, a $0.45 \mu \mathrm{m}$ membrane filter, and a $0.1 \mu \mathrm{m}$ membrane filter.

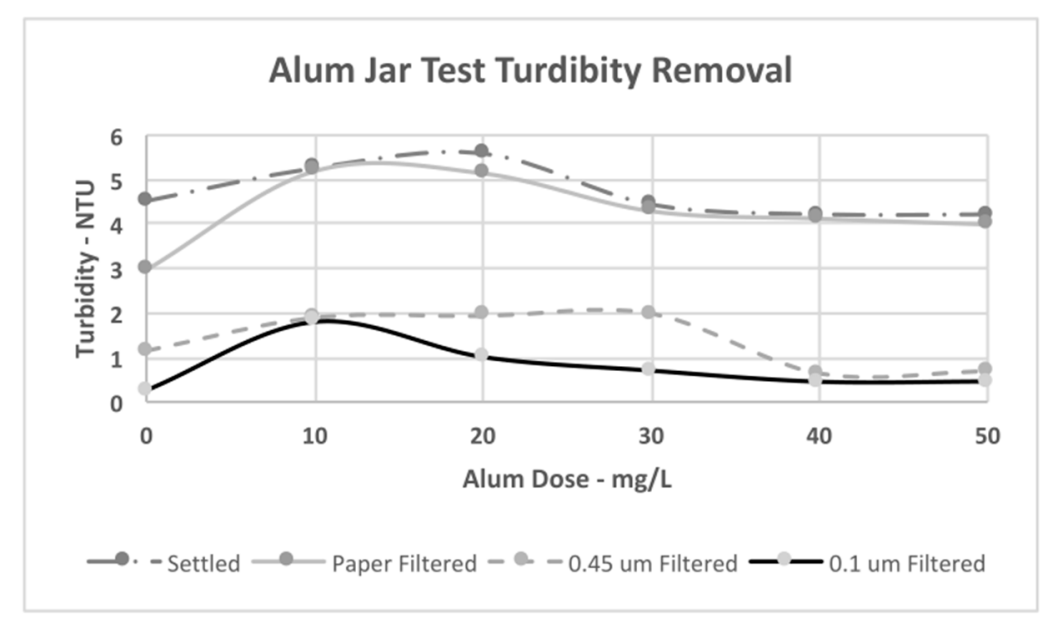

Figure 4. Turbidity after settling versus alum dose and filtering through $8 \mu \mathrm{m}$ filter paper, a $0.45 \mu \mathrm{m}$ membrane filter, and a $0.1 \mu \mathrm{m}$ membrane filter. 


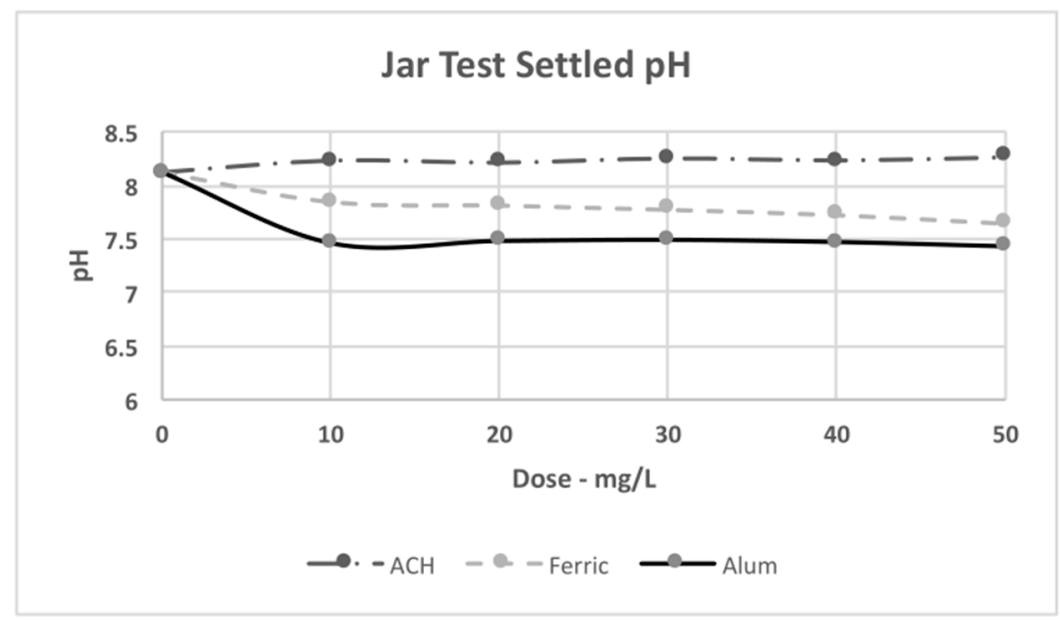

Figure 5. Jar test settled $\mathrm{pH}$ versus coagulant dose.

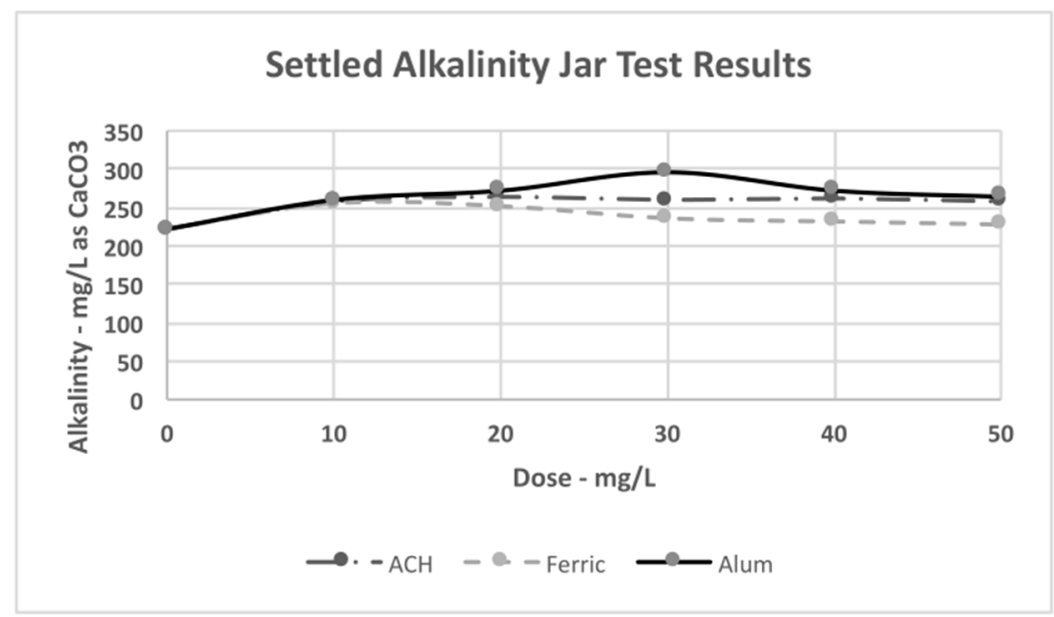

Figure 6. Jar test settled alkalinity versus coagulant dose.

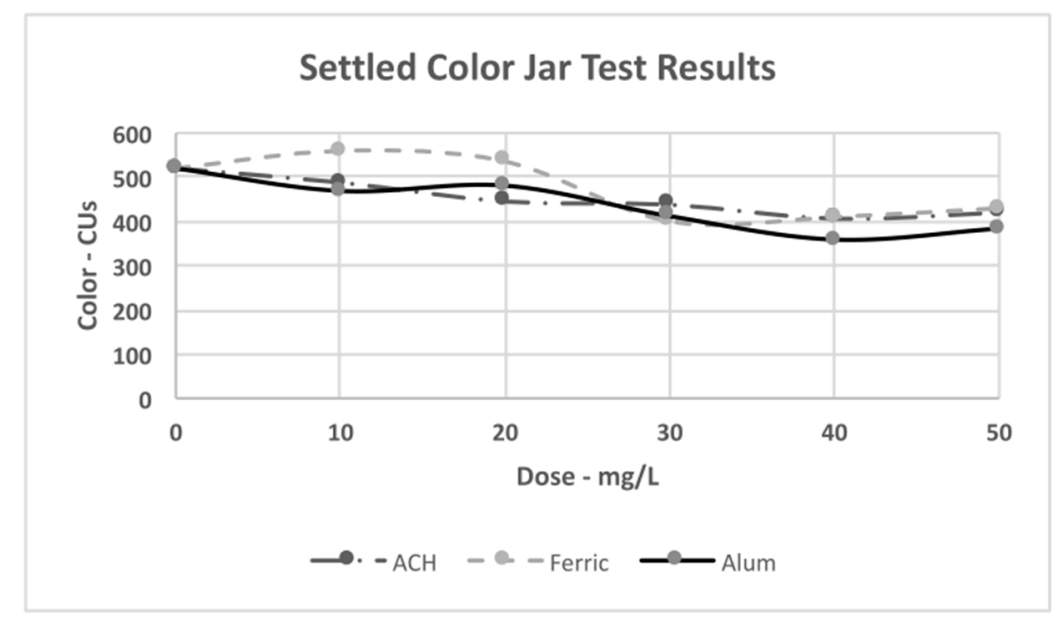

Figure 7. Jar test settled color versus coagulant dose.

ACH generally increased $\mathrm{pH}$ (Figure 4) and alkalinity (Figure 5), whereas ferric and alum lowered $\mathrm{pH}$ and alkalinity. Alum was most effective for color removal (28 percent) at a dose of $40 \mathrm{mg} / \mathrm{L}$. 


\subsection{SWRO Treatability Results}

The feed flow rate during SWRO testing was $75 \mathrm{~L} / \mathrm{h}$. The permeate flow rate was $7.95 \mathrm{~L} / \mathrm{h}$ and $9.2 \mathrm{~L} / \mathrm{h}$ during treatment of SSW and POW, respectively. An average recovery of 10.6 percent and 12.2 percent was achieved for SSW and POW, respectively.

SWRO water quality test results for SSW and POW are presented in Tables 4 and 5, respectively. Salinity (Figure 8), conductivity (Figure 9), total dissolved solids (TDS) (Figure 10), chloride (Figure 11), sulfate (Figure 12), and turbidity (Figure 13) were all removed. SWRO contaminant rejection is summarized in Figure 14.

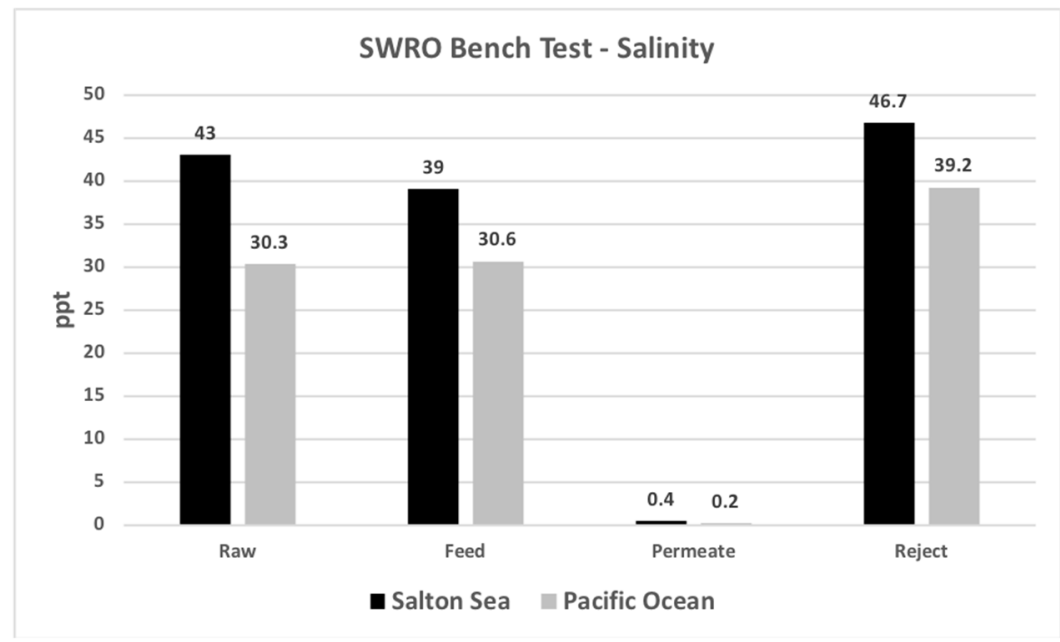

Figure 8. Salinity of raw water, SWRO feed, permeate, and reject flow.

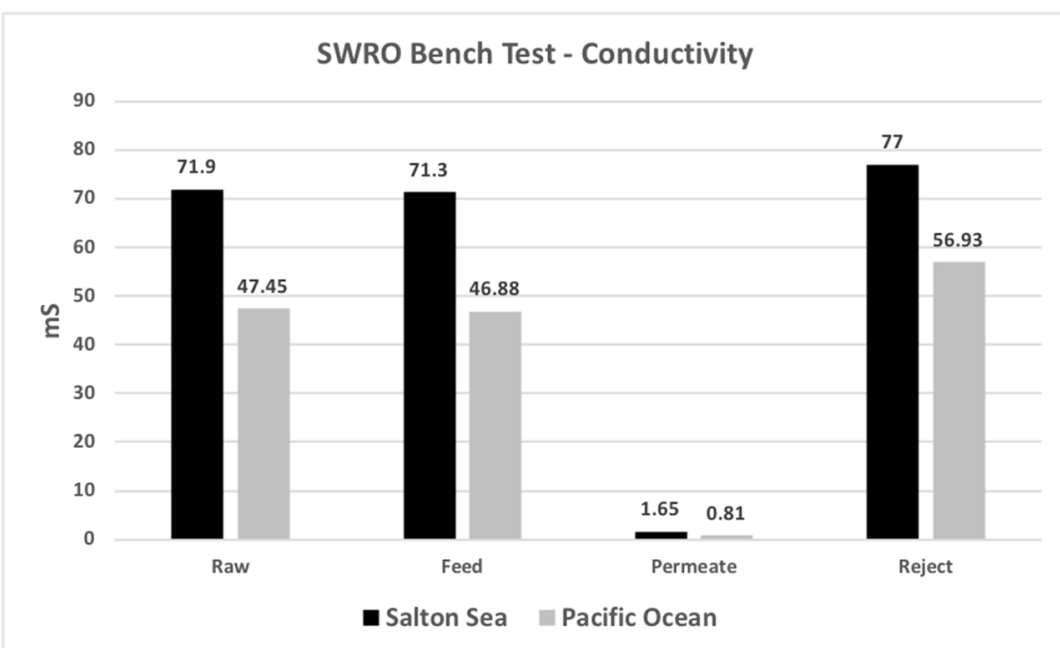

Figure 9. Conductivity of raw water, SWRO feed, permeate, and reject flow. 


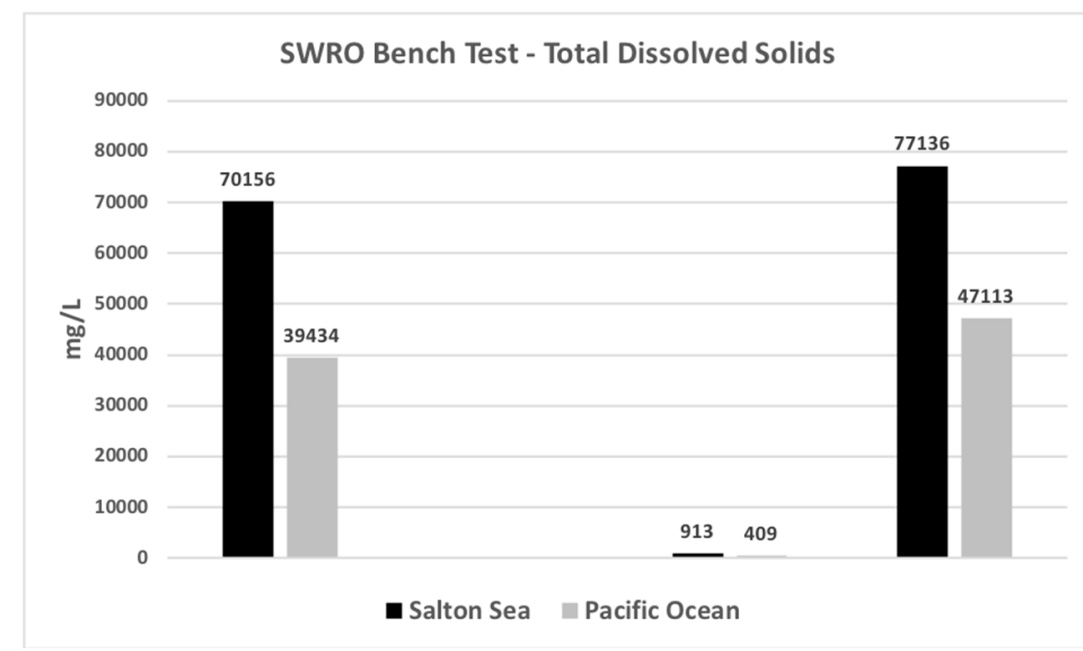

Figure 10. Total dissolved solids (TDS) of raw water, SWRO feed, permeate, and reject flow. TDS = total solids - suspended solids.

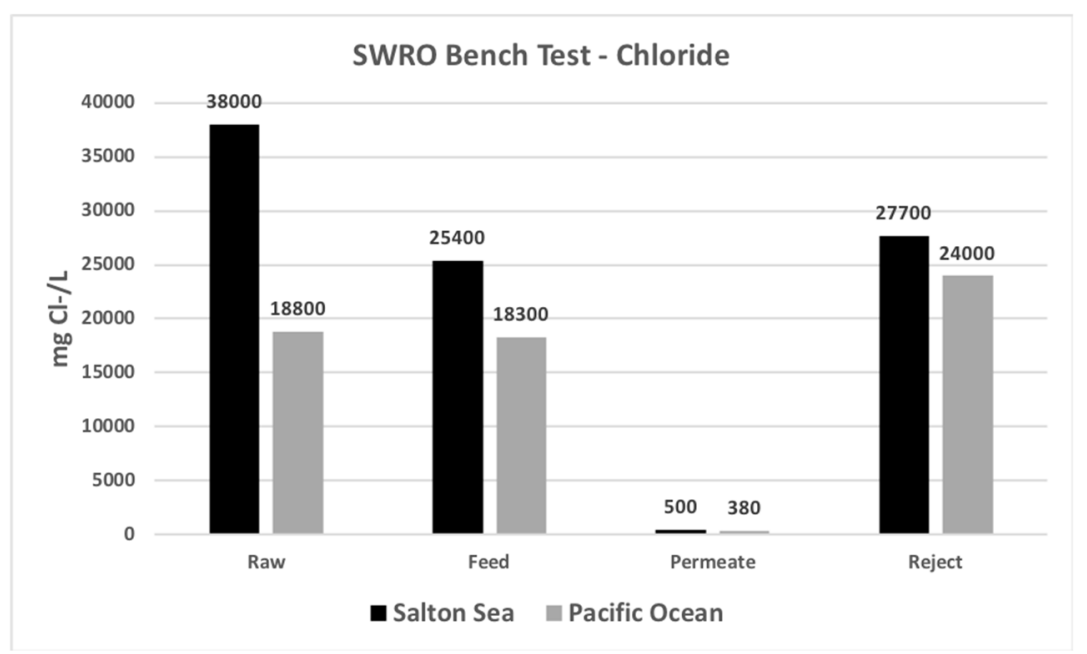

Figure 11. Chloride of raw water, SWRO feed, permeate, and reject flow.

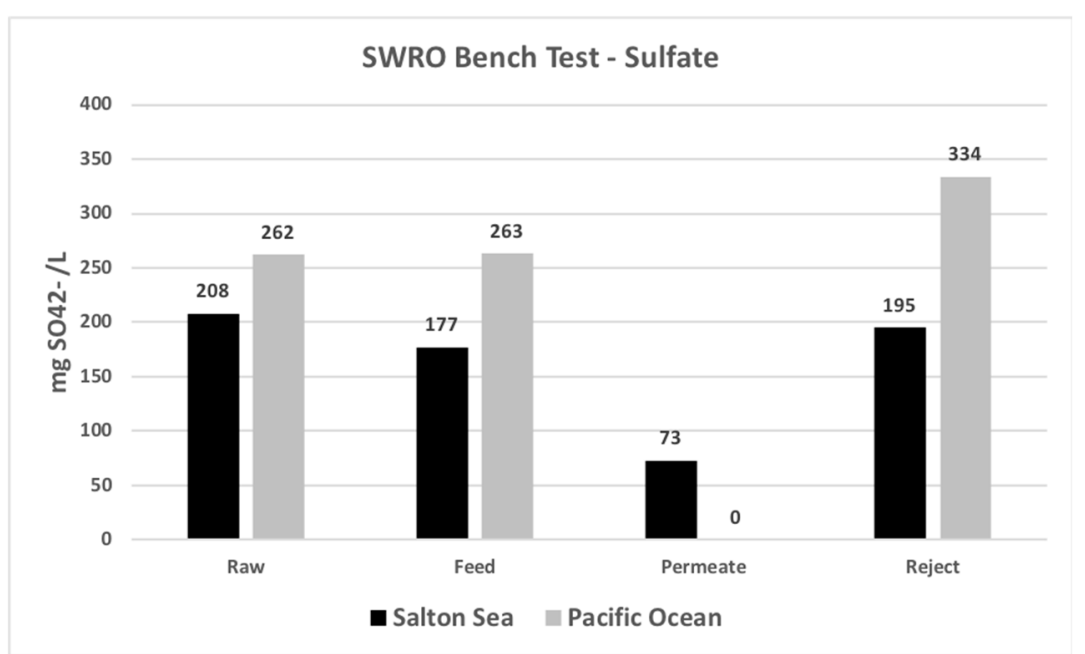

Figure 12. Sulfate of raw water, SWRO feed, permeate, and reject flow. 


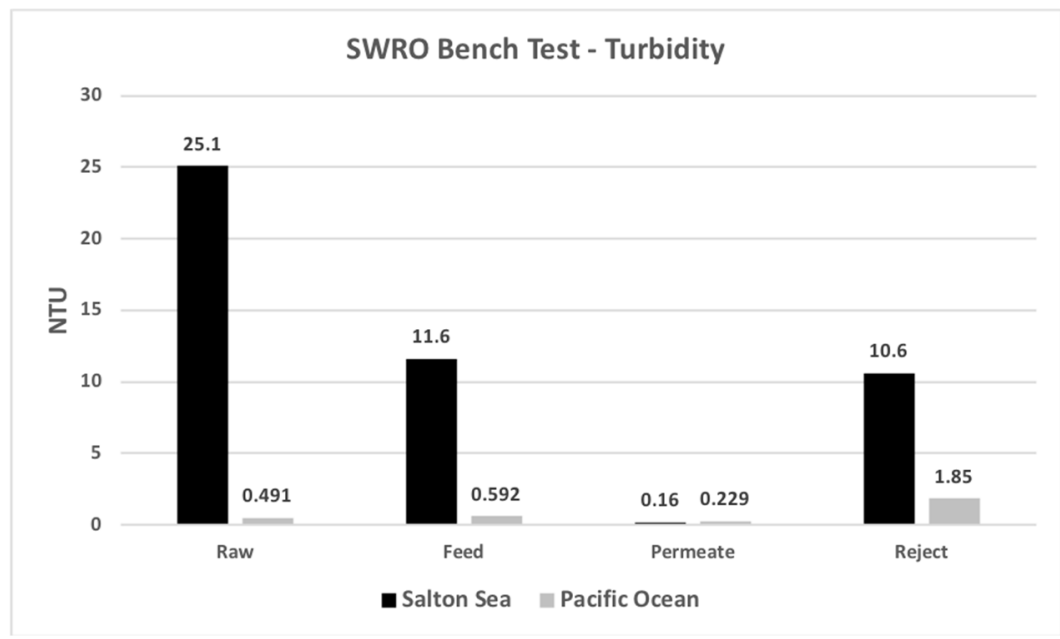

Figure 13. Turbidity raw water, SWRO feed, permeate, and reject flow.

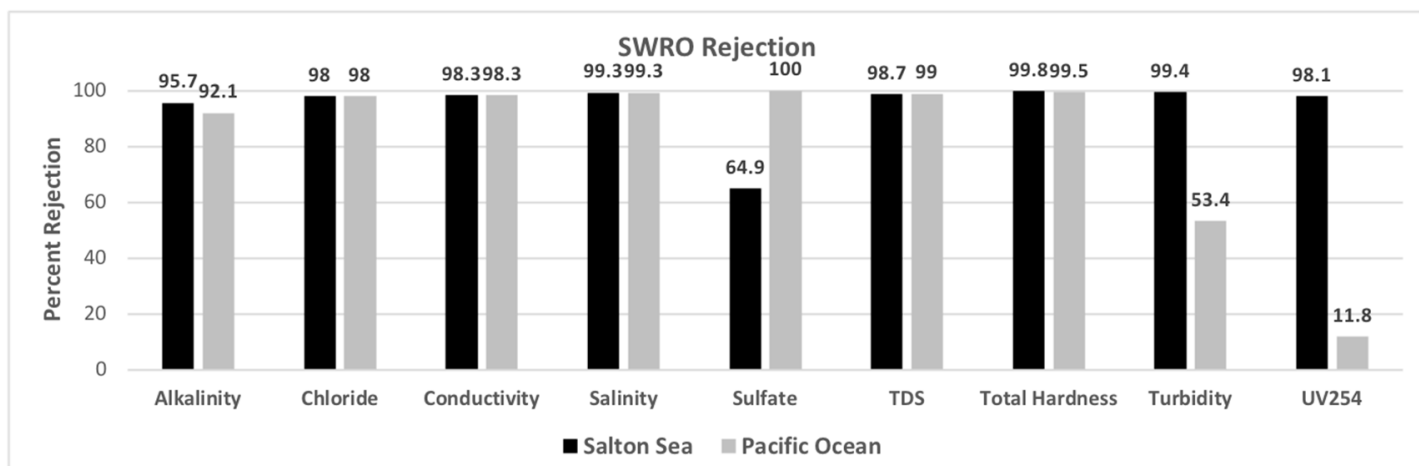

Figure 14. SWRO contaminant rejection.

\section{Discussion}

High salinity, TDS, sulfate, chloride, and color make treatment of Salton Sea water challenging. High sulfate concentrations coupled with warm temperatures and low redox potentials are present much of the year. These conditions result in sulfate reduction, producing hydrogen sulfide, which effects the iron geochemistry of the lake [9]. Lake mixing events during the summer have adverse effects on the fish and invertebrates in the Sea, as well as migrating birds feeding on them [11].

Coagulation of SSW with alum was found to be most effective for color removal at dosages characteristic of drinking water treatment, although residual color was still very high. Primary production in the Salton Sea is limited by phosphorus. Treating Salton Sea inflow water with alum to remove soluble phosphorus has been considered [29], but requires higher chemical dosages than considered here. The Salton Sea is supersaturated with respect to calcite and gypsum [30,31], potentially limiting the long-term feasibility of SWRO treatment to meet drinking water quality standards.

Drinking water utilities using $\mathrm{RO}$ can consistently meet treated drinking water regulatory limits [32,33]. To ensure regulatory compliance, water utilities establish site-specific treated water quality goals that are more strict than regulatory requirements. A comparison of the RO permeate quality achieved here to typical drinking water quality goals is provided in Table 6. Bench tests of SWRO effectively removed contaminants examined here from SSW, except for chloride and TDS. POW permeate only exceeded the chloride water quality goal. Chloride and TDS are regulated in the United States as National Secondary Drinking Water Regulations, which are recommended limits to ensure that drinking water is palatable. Permeate exceeding the recommended limit for chloride and TDS does not pose an adverse health risk, but may affect the taste of the water for some people. 
Table 6. RO Permeate Quality Compared to Typical Drinking Water Quality Goals ${ }^{1}$.

\begin{tabular}{ccccc}
\hline Constituent & Units & Goal $^{2}$ & Salton Sea & Pacific Ocean \\
\hline Alkalinity & $\mathrm{mg} / \mathrm{L}$ as CaCO & $\mathrm{NA}^{3}$ & 12 & 10 \\
Aeromonas & $\mathrm{CFU} / \mathrm{mL}$ & $\mathrm{None}^{2}$ & $\mathrm{None}$ & None \\
$\mathrm{Ca}^{2+}$ Hardness & $\mathrm{mg} / \mathrm{L} \mathrm{as} \mathrm{CaCO}_{3}$ & $\mathrm{NA}^{3}$ & 14 & 4 \\
Chloride & $\mathrm{mg} \mathrm{Cl} / \mathrm{L}$ & $<250$ & 500 & 380 \\
Color & $\mathrm{CU}$ & $\mathrm{ND}$ & 58 & $\mathrm{ND}$ \\
Conductivity & $\mathrm{mS}$ & $\mathrm{NA}$ & 1.65 & 0.82 \\
HPC & $\mathrm{CFU} / \mathrm{mL}$ & $<500$ & 14 & 1 \\
pH & $\mathrm{units}$ & $7.0-8.5^{3}$ & 7.9 & 7.5 \\
Salinity & $\mathrm{ppt}$ & $\mathrm{NA}$ & 0.4 & 0.2 \\
Sulfate & $\mathrm{mg} \mathrm{SO}{ }^{2-} / \mathrm{L}$ & $<250$ & $\mathrm{ND}$ & $\mathrm{ND}$ \\
Suspended Solids & $\mathrm{mg} / \mathrm{L}$ & $\mathrm{None}$ & $\mathrm{ND}$ & 1 \\
Total Coliform & $\mathrm{CFU} / \mathrm{mL}$ & $\mathrm{None}$ & - & - \\
Total Hardness & $\mathrm{mg} / \mathrm{L} \mathrm{as} \mathrm{CaCO}$ & $50-100$ & 38 & 24 \\
Total Solids & $\mathrm{mg} / \mathrm{L}$ & $<500$ & 913 & 410 \\
Turbidity & $\mathrm{NTU}$ & $<0.3$ & 0.16 & 0.229 \\
UV254 & $\mathrm{cm}{ }^{-1}$ & $\mathrm{NA}$ & 0.013 & 0.015 \\
\hline
\end{tabular}

Note: ${ }^{1} \mathrm{NA}=$ not applicable; $\mathrm{ND}=$ none detected; - = not tested; ${ }^{2}$ Goals based on meeting USEPA drinking water regulations $[33,34] ;^{3}$ Alkalinity, $\mathrm{pH}$ and calcium must be adjusted to render the water noncorrosive.

The U.S. Environmental Protection Agency (USEPA) requires filtration and disinfection treatment for surface water sources of drinking water [33]. Jar tests indicate $0.1 \mu \mathrm{m}$ pore microfiltration pretreatment will consistently achieve a treated water turbidity limit of $0.3 \mathrm{NTU}$. The membrane fouling potential is very high for SSW, which must be further assessed. To lessen chemical fouling of $\mathrm{RO}$, softening pretreatment should be considered for lowering calcium and total hardness feed concentrations. The recovery achieved (10 percent) is typical for a single membrane element under these test conditions. The recovery that could achieved by a membrane array treating Salton Sea water must be further evaluated.

In general, high-salinity eutrophic waters are difficult to treat, and are typically avoided as water supply sources. Lower-salinity surface waters, ground waters, and even desalinated sea water are generally preferred when available. The SWRO bench tests conducted here examined only initial contaminant rejection from SSW and POW in the laboratory. Results suggest that treatment of Salton Sea water to meet potable water quality goals is possible, at least at the bench scale. Based on these results, an integrated membrane system consisting of microfiltration, membrane softening, and SWRO is the most promising for treating Salton Sea water. Additional pilot testing at the Salton Sea will be necessary to assess the long-term feasibility of SWRO treatment of Salton Sea water for potential urban water use.

Coastal area desalination plants typically dispose of concentrate by ocean discharge. Concentrate disposal options are more limited for desalination of inland waters such as the Salton Sea, where ocean discharge is not feasible. If large-scale desalination of Salton Sea water is pursued, concentrate disposal must be addressed, regardless of the specific desalination technology selected [34,35]. Concentrate disposal options include well injection, evaporation ponds, or further concentration using vapor compression evaporation. Importation of water from Mexico into the Salton Sea, suggested as a long-term remediation solution [15], could also impact the feasibility of RO desalination and brine disposal for potable water production.

Countries in the Arabian Gulf rely on desalination using distillation technologies (multi-effect and multi-stage) [36]. Should geothermal energy development at the Salton Sea progress to the point of providing an economical supply of energy, distillation technology may provide a viable alternative to RO. Currently, RO is the most economical of desalination technologies for potable water treatment. In December 2015, the largest desalination plant in the United States began operation at Carlsbad, California. The plant provides 50 million gallons per day of RO-treated Pacific Ocean water to the 
customers of the San Diego County Water Authority [37], further demonstrating the feasibility of SWRO for producing potable water.

Acknowledgments: This research was financially supported in summer 2017 by a micro-grant from the CBU Gordon and Jill Bourns College of Engineering. No funding was received for covering the costs to publish in open access. CBU graduate student Gowthami Pediredla performed a portion of the laboratory analyses for this study.

Conflicts of Interest: The author declares no conflict of interest. The funding sponsors had no role in the design of the study; in the collection, analyses, or interpretation of data; in the writing of the manuscript, and in the decision to publish the results.

\section{References}

1. Dugan, H.A.; Bartlett, S.L.; Burke, S.M.; Doubek, J.P.; Krivak-Tetley, F.E.; Skaff, N.K.; Summers, J.C.; Farrell, K.J.; McCullough, I.M.; Morales-Williams, A.M.; et al. Salting our freshwater lakes. Proc. Natl. Acad. Sci. USA 2017, 114, 4453-4458. [CrossRef] [PubMed]

2. Ghaly, F.M. Role of natural vegetation in improving salt affected soil in northern Egypt. Soil Tillage Res. 2002, 64, 173-178. [CrossRef]

3. Jenke, A.L. Evaluation of Salinity Created by Irrigation Return Flows; EPA 430/9-74-006; USEPA Office of Water Programs: Washington, DC, USA, 1974.

4. Yihdego, Y.; Webb, J. Modelling of seasonal and long-term trends in lake salinity in southwestern Victoria, Australia. J. Environ. Manag. 2012, 112, 149-159. [CrossRef] [PubMed]

5. Tran, Q.K.; Jassby, D.; Schwabe, K.A. The implications of drought and water conservation on the reuse of municipal wastewater: Recognizing impacts and identifying mitigation possibilities. Water Res. 2017, 124, 472-481. [CrossRef] [PubMed]

6. California Department of Water Resources. Salton Sea Ecosystem Restoration Program. Available online: www.water.ca.gov/saltonsea/ (accessed on 3 January 2018).

7. James, I. California has a new \$383 million plan for the shrinking Salton Sea. The Desert Sun, 16 March 2017. Available online: http:/ / www.desertsun.com/story/news/environment/2017/03/16/california-has-new383-million-plan-shrinking-salton-sea/99124850/ (accessed on 9 January 2018).

8. Dillon, J.G.; McMath, L.M.; Trout, A.L. Seasonal Changes in bacterial diversity in the Salton Sea. Hydrobiologia 2009, 632, 49-64. [CrossRef]

9. De Koff, J.P.; Anderson, M.A.; Amrhein, C. Geochemistry of iron in the Salton Sea, California. Hydrobiologia 2008, 604, 111-121. [CrossRef]

10. LeBlanc, L.A.; Kuivila, K.M. Occurrence, distribution and transport of pesticides into the Salton Sea Basin, California, 2001-2002. Hydrobiologia 2008, 604, 151-172. [CrossRef]

11. Reese, B.K.; Anderson, M.A.; Amrheim, C. Hydrogen sulfide production and volatilization in a polymictic eutrophic saline lake, Salton Sea, California. Sci. Total Environ. 2008, 406, 205-218. [CrossRef] [PubMed]

12. Cohen, M.J. Hazard's Toll: The Costs of Inaction at the Salton Sea; Pacific Institute: Oakland, CA, USA, 2014; Available online: http:/ / pacinst.org/publication/hazards-toll/ (accessed on 14 February 2018).

13. US Bureau of Reclamation. Restoration of the Salton Sea; Summary Report; US Department of the Interior: Washington, DC, USA, 2007.

14. Tetra Tech, Inc. Review of US Filter Corporation Salton River Proposal Final Report; TC 10138-41; Tetra Tech, Inc.: Pasadena, CA, USA, 2003.

15. Solis, G. How Water from Mexico Can Save the Salton Sea. The Desert Sun, Undated. Available online: https:/ / www.desertsun.com/story/news/environment/2016/03/23/how-water-mexico-can-savesalton-sea/82163024/ (accessed on 16 February 2018).

16. California Water Boards. "State Water Board Adopts Order on Long-Term Management of Salton Sea." Press Release. 7 November 2017. Available online: https:/ /www.waterboards.ca.gov/press_room/press_ releases/2017/pr110717_salton_sea.pdf (accessed on 16 February 2018).

17. Global Water Intelligence. Desalination Markets 2016; Media Analytics Ltd.: Oxford, UK, 2016; Available online: https: / /www.desaldata.com/desalination-markets-2016 (accessed on 9 January 2018).

18. UNESCO. Energy Requirements of Desalination Processes. Encyclopedia of Desalination and Water Resources (DESWARE). Available online: http:/ / www.desware.net/Energy-Requirements-DesalinationProcesses.aspx (accessed on 15 February 2018). 
19. US Bureau of Reclamation. Salton Sea Projects Map. 16 April 2015. Available online: https://usbr.gov/lc/ region/programs/SaltonSeaProjectsMap.pdf (accessed on 15 February 2018).

20. Younker, L.W.; Kasameyer, P.W.; Tewhey, J.D. Geological, Geophysical, and Thermal Characteristics of the Salton Sea Geothermal Field, California. J. Vulcanol. Geotherm. Res. 1982, 12, 221-258. [CrossRef]

21. McGuire, J.J.; Lohman, R.B.; Catchings, R.D.; Rymer, M.J.; Goldman, M.R. Relationships among seismic velocity, metamorphism, and seismic and aseismic fault slip in the Salton Sea Geothermal Field region. J. Geophys. Res. Solid Earth 2015, 120, 2600-2615. [CrossRef]

22. Penn, I. Australian Firm Plans Nation's Largest Geothermal Plant in Imperial Valley. Los Angeles Times, 14 January 2017. Available online: http:/ / www.latimes.com/business/la-fi-geothermal-salton-sea-20170114story.html (accessed on 15 February 2018).

23. ASTM D 2035-08. Standard Practice for Coagulation-Flocculation Jar Test of Water; American Society of Testing and Materials: West Conshohocken, PA, USA, 2008.

24. Parker Hannifin Corporation, Racor Division/Village Marine Tec., Carson, California. Available online: www.villagemarine.com (accessed on 9 January 2018).

25. American Public Health Association (APHA). Standard Methods for the Examination of Water and Wastewater, 20th ed.; American Public Health Association: Washington, DC, USA, 1998.

26. United States Environmental Protection Agency (USEPA). Methods Approved to Analyze Drinking Water Samples to Ensure Compliance with Regulations. Available online: https://www.epa.gov/ dwanalyticalmethods (accessed on 9 January 2018).

27. Hach. Loveland, Colorado. Available online: www.hach.com/wateranalysis (accessed on 9 January 2018).

28. Micrology Laboratories. Goshen, Indiana. Available online: www.micrologylabs.com (accessed on 9 January 2018).

29. Rodriguez, I.R.; Amrhein, C.; Anderson, M.A. Reducing dissolved phosphorus loading to the Salton Sea with aluminum sulfate. Hydrobiologia 2008, 604, 37-44. [CrossRef]

30. Holdren, G.C.; Montaño, A. Chemical and physical characteristics of the Salton Sea, California. Hydrobiologia 2002, 473, 1-21. [CrossRef]

31. Rodriguez, I.R.; Amrhein, C.; Anderson, M.A. Laboratory studies on the coprecipitation of phosphate with calcium carbonate in the Salton Sea, California. Hydrobiologia 2008, 604, 45-55. [CrossRef]

32. United States Environmental Protection Agency (USEPA). Edition of the Drinking Water Standards and Health Advisories; EPA 822-S-12-001; Office of Water: Washington, DC, USA, 2012.

33. Pontius, F.W. Regulatory Compliance Planning to Ensure Water Supply Safety. J. AWWA 2002, 94, 52-64. [CrossRef]

34. Morillo, J.U. Comparative study of brine management technologies for desalination plants. Desalination 2014, 336, 32-49. [CrossRef]

35. Voutchkov, N. Overview of seawater concentrate disposal alternatives. Desalination 2011, 273, $205-219$. [CrossRef]

36. Global Water Intelligence. IDA Desalination Yearbook Water Desalination Report 2017-2018; Media Analytics Ltd.: Oxford, UK, 2017.

37. San Diego County Water Authority. Fact Sheet: Seawater Desalination; The Claude "Bud" Lewis Desalination Plant and Related Facilities. October 2017. Available online: http:/ / www.sdcwa.org/sites/default/files / desal-carlsbad-fs-single.pdf (accessed on 9 January 2018).

(C) 2018 by the author. Licensee MDPI, Basel, Switzerland. This article is an open access article distributed under the terms and conditions of the Creative Commons Attribution (CC BY) license (http://creativecommons.org/licenses/by/4.0/). 